\title{
Inflation Performance and Constitutional Central Bank Independence: Evidence from Latin America and the Caribbean
}

\section{Eva Gutiérrez*}

Fecha de recepción: 10 de noviembre de 2003; fecha de aceptación: 15 de marzo de 2004.

Abstract: This paper explores the relationship between the constitutional entrenchment of central bank independence and inflation performance. Empirical studies for developing countries have not found a relationship between central bank independence, proxied by the de jure independence established in the central bank law, and inflation. We argue that the Constitution is likely to be better enforced than ordinary statutes owing to its higher legal rank. Our empirical analysis finds that in a sample of Latin American and Caribbean countries, those countries that entrench the independence of the central bank in the Constitution have a better inflation performance.

Keywords: central bank independence, inflation, Latin American countries.

Resumen: Ese artículo analiza la relación entre la introducción de disposiciones constitucionales que dotan de independencia a los bancos centrales, y la evolución de la inflación. La literatura empírica no encuentra una relación entre la independencia del banco central, aproximada por la independencia de jure conforme a la ley o estatutos del banco central, y la inflación en los países en vías de desarrollo. Este artículo argumenta que en general la Constitución, debido a su status legal superior, suele implementarse mejor que otras leyes o estatutos de menor rango legal. Nuestro análisis empírico encuentra, para un muestra consistente en los países latinoamericanos y caribeños, que aquellos países que sustentaron

* Monetary Exchange and Affairs Department, International Monetary Fund, egutierrez@ imf.org. I want to thank Tony Lybek, Abdourahmane Sarr and Alan Ize, as well as participants in an IMF seminar, for their comments. Any remaining mistakes are my own. The views expressed in this Working Paper are those of the author and do not necessarily represent those of the IMF or IMF policy. Working Papers describe research in progress by the author(s) and are published to elicit comments and to further debate. 
la independencia del banco central en disposiciones constitucionales tienen menor inflación, controlando por otros factores.

Palabras clave: independencia del banco central, inflación, América Latina.

\section{Introduction}

T $\mathrm{n}$ the early 1980's, a body of the monetary economics literature 1 postulated that an autonomous and accountable central bank facilitates price stability. The more the central bank is formally separated from the government's short-term influence on monetary policy, the more the inflation bias will be reduced, provided that the central bank is held accountable for its monetary policy performance. Since then, several countries have reformed their central bank legislations to enhance the autonomy and accountability of the central bank. In many cases, international financial institutions (IFIs) provided technical assistance in this area to developing and transition countries. Moreover, central bank legislation reform was often a condition for the disbursement of loans granted by these institutions. Some countries, in many cases after they had experienced a period of high inflation, made an additional effort to also entrench central bank independence in the Constitution.

Several empirical studies have looked at the relationship between inflation and the central bank legislation. The results indicate that inflation is negatively correlated with the degree of de jure autonomy of the central bank in industrialized countries but not in developing countries. A possible explanation is that enforcement of the legislation is weaker in developing countries. Therefore, in these countries, the de jure autonomy of the central bank is a poor proxy for its de facto autonomy. Some studies used the turnover rate of governors as an alternative measure of the de facto autonomy of the central bank. However, as discussed in Section II, results were mixed.

This paper proposes an alternative proxy for the de facto autonomy of the central bank, based exclusively in the degree of autonomy granted to the central bank by the Constitution. There are several reasons why constitutional provisions regarding the central bank might reflect the true degree of autonomy of the institution better than the central bank charter. Even in countries with less than perfect legal enforcement systems, the Constitution is likely to be better enforced than ordinary statutes due to its higher legal rank. Claims on the violation 
of constitutional provisions can only be addressed by the Constitutional Court, typically including the most respected judges in the country. The members of the court hold long-term positions, which help detach them from government influence. In addition, constitutional entrenchment might enhance central bank independence, particularly in environments where the government or the governing coalition with a legislative majority attempts to influence central bank policies. This is so because modifications in the Constitution tend to require qualified majorities, eliminating potential threats to make changes in the legal status of the central bank. Furthermore, constitutional entrenchment of central bank independence reflects a wide political and social consensus regarding the status and objectives of the central bank, which is likely to be translated into de facto central bank independence. Surprisingly, the relationship between inflation performance and the constitutional provisions on central banking has yet to be empirically studied.

This paper explores the relationship between the constitutional entrenchment of central bank independence and inflation performance in Latin American countries. Typically, the extent to which central bank independence is reflected in the Constitution depends on several factors, such as the country's economic system, legislative tradition, its degree of economic development and its economic history. ${ }^{1}$ Many Latin American countries experienced hyperinflation and economic recession during the 1980's partly owing to expansionary monetary policies that accommodated fiscal expenditures. Constitutional reforms in the late 1980's and early 1990's in several Latin American countries introduced a chapter devoted to the central bank, with provisions explicitly establishing the autonomy of the central bank, and mechanisms for the supervision of its functions. Moreover, provisions explicitly prohibiting the central bank from providing direct credit to the government were also introduced. Both the richness of constitutional detail regarding the central bank, and the fact that the constitutional reforms were introduced several years ago, make Latin American countries the most adequate sample to use in a study of the relationship between inflation performance and entrenchment of central bank independence and accountability in the Constitution.

\footnotetext{
${ }^{1}$ For a detailed survey on constitutional provisions in central bank independence and accountability, see Gutiérrez (2000), "Central Banking and Constitution: Cross Country Survey", available from the author upon request.
} 
The rest of the paper is organized as follows. Section I provides an overview of the literature on central bank independence and inflation performance. Section II describes the index constructed to measure the degree of central bank independence based on the constitutional provisions on central banking. Section III explores the relationship between this index and inflation performance in Latin American and Caribbean countries. Finally, section IV summarizes the conclusions.

\section{Review of the Literature ${ }^{2}$}

The theoretical literature has provided three complementary arguments to explain why delegation of monetary policy to an independent central bank would yield, ceteris paribus, lower inflation rates. The first two arguments relate to the fiscal position of the government, whilst the third argument deals with the time-inconsistency issues. However, it is important to notice that central bank independence would matter to the extent that the central bank authorities are primarily concerned with price stability.

The first argument indicates that the government will be inclined to exert political pressure on the monetary authorities to relax monetary conditions. Restrictive monetary policy tends to worsen the fiscal position of the government through a reduction in seigniorage revenue, increase in the interest burden of the debt and lower tax receipts because of the temporary economic slowdown. Political independence allows the central bank to resist government pressures to ease monetary conditions.

The second argument points out that, when monetary authorities are forced to finance government deficits by printing money, money supply becomes endogenous. However, a central bank enjoying economic independence will force the government to reduce the deficit.

Finally, the third argument in favor of central bank independence notices that governments typically have short-term objectives which are inconsistent with the longer horizon objectives. Governments, for example, might attempt to temporarily stimulate the economy through a monetary expansion, exploiting price rigidities, at the cost of future higher inflation. Lack of credibility in the government commitment to the announced inflation objective leads rational economic agents to

2 This section draws heavily in Eijffinger and De Haan (1996). 
demand a risk premium to compensate for this inflationary bias. Delegation of monetary policy to an independent central bank solves the government time-inconsistency problem and eliminates the growthhampering risk premium. However, the theoretical literature has also pointed out that an independent central bank should be accountable and coordinate its policies with the government. The institution to which the responsibility over monetary policy is delegated should be accountable to democratically elected representatives and to the public in general. Also, coordination of monetary and fiscal policy is important to achieve higher output growth and lower inflation. ${ }^{3}$

The theoretical literature contains alternative views with respect to the effect of central bank independence on the level of economic growth. On the one hand, low levels of inflation result in temporarily high real interest rates, with the subsequent negative effect on economic growth. On the other hand, low and stable inflation rates reduce risk premium interest rates, thereby stimulating economic growth.

Traditionally, the empirical literature has focused on the relationship between the de jure independence of the central bank and inflation performance. ${ }^{4}$ Alesina (1988, 1989), Grilli, Masciandaro and Tabellini (1991), Eijffinger and Schaling (1993, 1995), Cukierman (1992) and Cukierman, Webb and Neyapti (1992) are among the first studying this relationship. The authors constructed different indexes including categories such as: $i$ ) the location of responsibility over monetary policy; ii) whether members of the government sit on the governing body of the central bank; iii) appointment and dismissal procedures for the members of the governing body of the central bank, as well as the length of their office term; $i v$ ) the importance of price stability in comparison to other objectives; and $v$ ) constraints on the government's ability to borrow from the central bank. The indexes elaborated by these authors have been widely used in the empirical literature over different samples of countries. ${ }^{5}$ Most of the studies estimate the correlation between the average inflation rate and the index of central bank independence and have been criticized for not including appropriate controls. How-

${ }^{3}$ See Andersen and Scheider (1986).

${ }^{4}$ However there are central banks whose independence is not entrenched in the law but in practice, accountability of the central bank and market reaction to central bank actions result in de facto independence.

5 The relevance of such indexes as a measure of the independence of the central bank has been criticized by Mangano (1998). He pointed out that the existing indicator differs considerably, and that even the common criteria considered in the different indexes are subject to interpretation differences. However, Berger et al. (2000) points out that his conclusions are severely affected by his normalization procedure. 
ever, a few studies include other variables such as a measure of political independence (Grilli, Masciandaro and Tabelini, 1991), and indicators of openness, exchange rate-fixity, and budget deficit (Al-Marhubi and Willet, 1995), or openness, political instability, and debt to GDP ratios (Campillo and Miron, 1997). Some of the studies have also been questioned because of sensitivity of the results to the sample period and inappropriate control of influential observations, which could bias the results. For example, Jacome (2001) concludes that those Latin American countries with higher de jure independence of the central bank, as reflected in the central bank legislation, have not experienced lower inflation than the rest of the countries in the region, once the observations for high inflation countries are removed. In any case, it is important to point that correlation does not imply causality. It is unclear if de jure independent central banks are more successful at fighting inflation, or if countries where the fight for inflation is considered a priority entrench the independence of the central bank in the law.

With few exceptions, ${ }^{6}$ most of the studies focus on industrialized countries. A review of the literature by Cukierman (1994) concludes that higher de jure independence is related to lower inflation in industrialized countries but not in developing countries. ${ }^{7}$ A more recent review of the latest empirical papers by Berger et al. (2000) also supports this view.

Central bank independence does not necessarily need to be entrenched in the law to ensure de facto independence. Accountability practices of the central bank and market reaction to central bank actions may enforce discipline in the central bank and government actions. However, measuring de facto independence is complicated. Several studies have looked at the turnover rate of central bank governors as a proxy for de facto independence of the central bank. The argument is that a high turnover of governors is a symptom of low degree of de facto political independence. Cukierman (1992) finds a negative correlation between turnover rates and inflation in its sample of devel-

\footnotetext{
${ }^{6}$ See Cukierman (1992), Cukierman, Webb and Neyapti (1992) and Campillo and Miron (1997).

7 This result is also found in Cukierman and Webb (1995), and De Haan and Siermann (1996). Lybek (1999) finds a negative correlation between average inflation in 15 former Soviet republics and an index of de jure independence that includes also categories regarding central bank accountability and mechanisms for policy coordination with the government. However, Malizewski (2000) and Cukierman et al. (2001) look at a sample of 26 transition economies and find a negative correlation between an index of central bank independence and inflation performance only for economies with a high degree of liberalization.
} 
oping countries, although the rest of the studies are less conclusive. De Haan and Koi (2000), using a sample of 89 developing countries, find that turnover rates are related to inflation only if the high inflation countries are included in the sample. Lybek (1999) and Jacome (2001) do not find a correlation between this variable and average inflation in a sample of former soviet republics and Latin American countries, respectively.

\section{A Constitutional Index of Central Bank Independence and Accountability}

In order to measure the de jure independence and accountability of the central bank based on the constitutional provisions, we ranked countries according to an index based on Lybek $(1998,1999)$. The index considers five broad criteria: $i$ ) the objectives of the central bank; ii) responsibilities of the central bank regarding monetary and exchange policy; iii) the degree of political autonomy of the central bank; $i v$ ) the degree of economic autonomy of the central bank; and $v$ ) accountability procedures to which the central bank is subjected. The following paragraphs describe the categories and how they affect independence and accountability, while Table 1 details the subcategories within the five broad criteria included in the index and the score given to each of them. ${ }^{8}$

\section{Central Bank Objectives}

A clear definition and prioritization of the objectives of the central bank enhances the credibility and effectiveness of monetary policy and facilitates accountability. Price stability —as the best contribution to sustained economic growth- should be the primary objective of the central bank. Other formulations, such as preserving the stability of the currency or preserving monetary stability, could pose a conflict between the internal and the external value of the currency. In addition, the central bank may support the economic policies of the government and pursue other objectives. However, clear priority to

\footnotetext{
${ }^{8} \mathrm{~A}$ review of best practices regarding central bank independence and accountability can be found in Lybek (1998).
} 


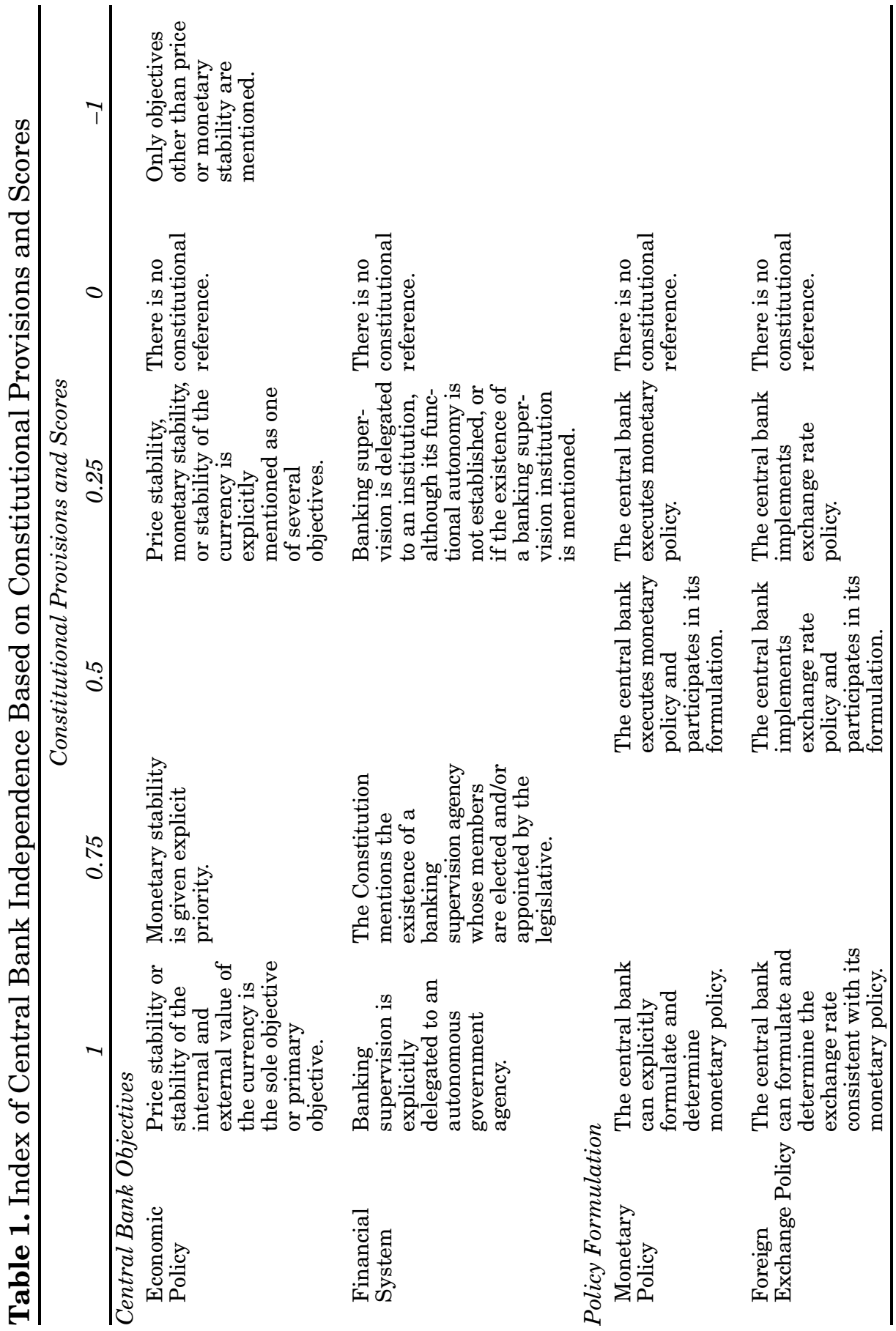




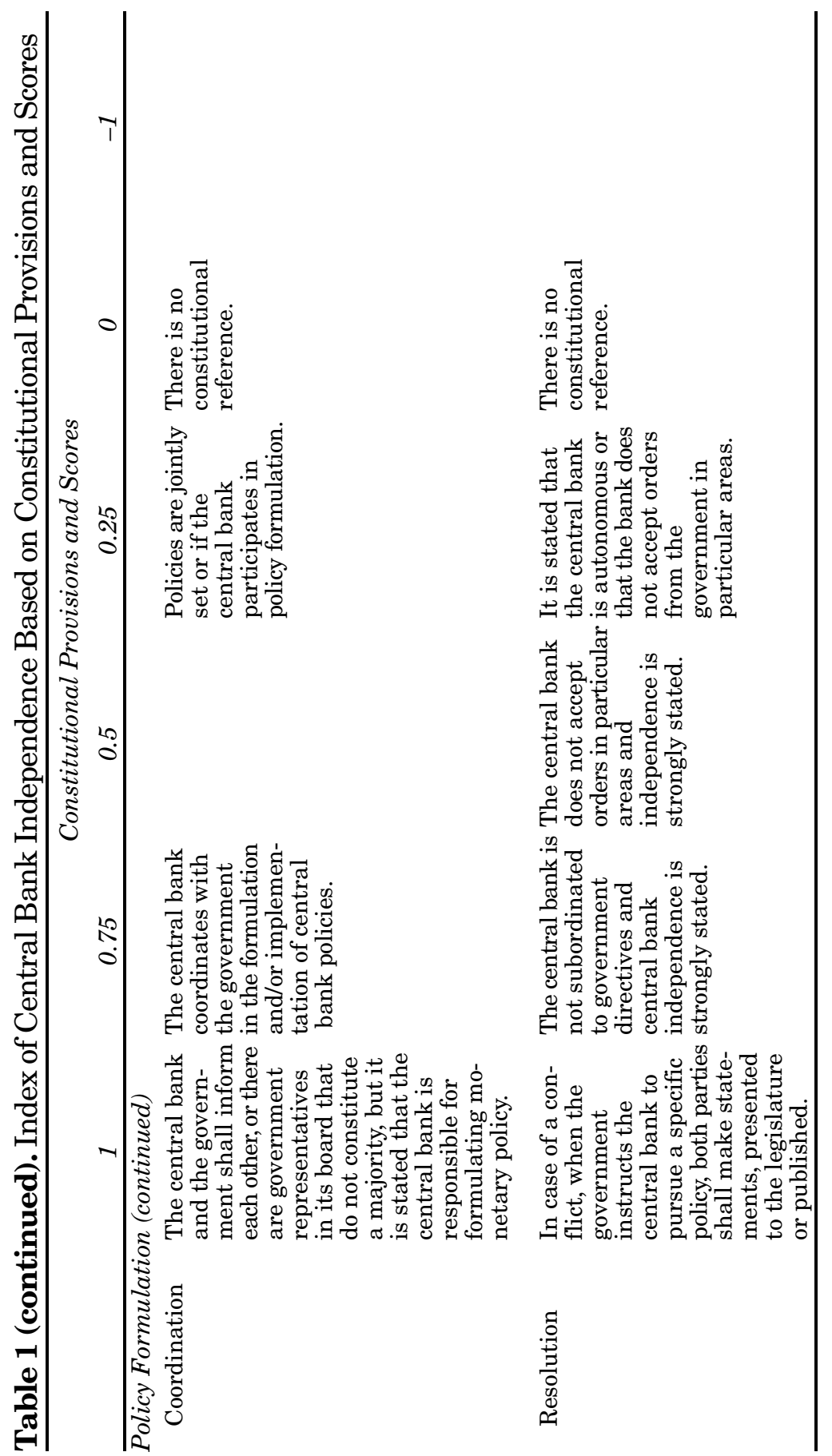




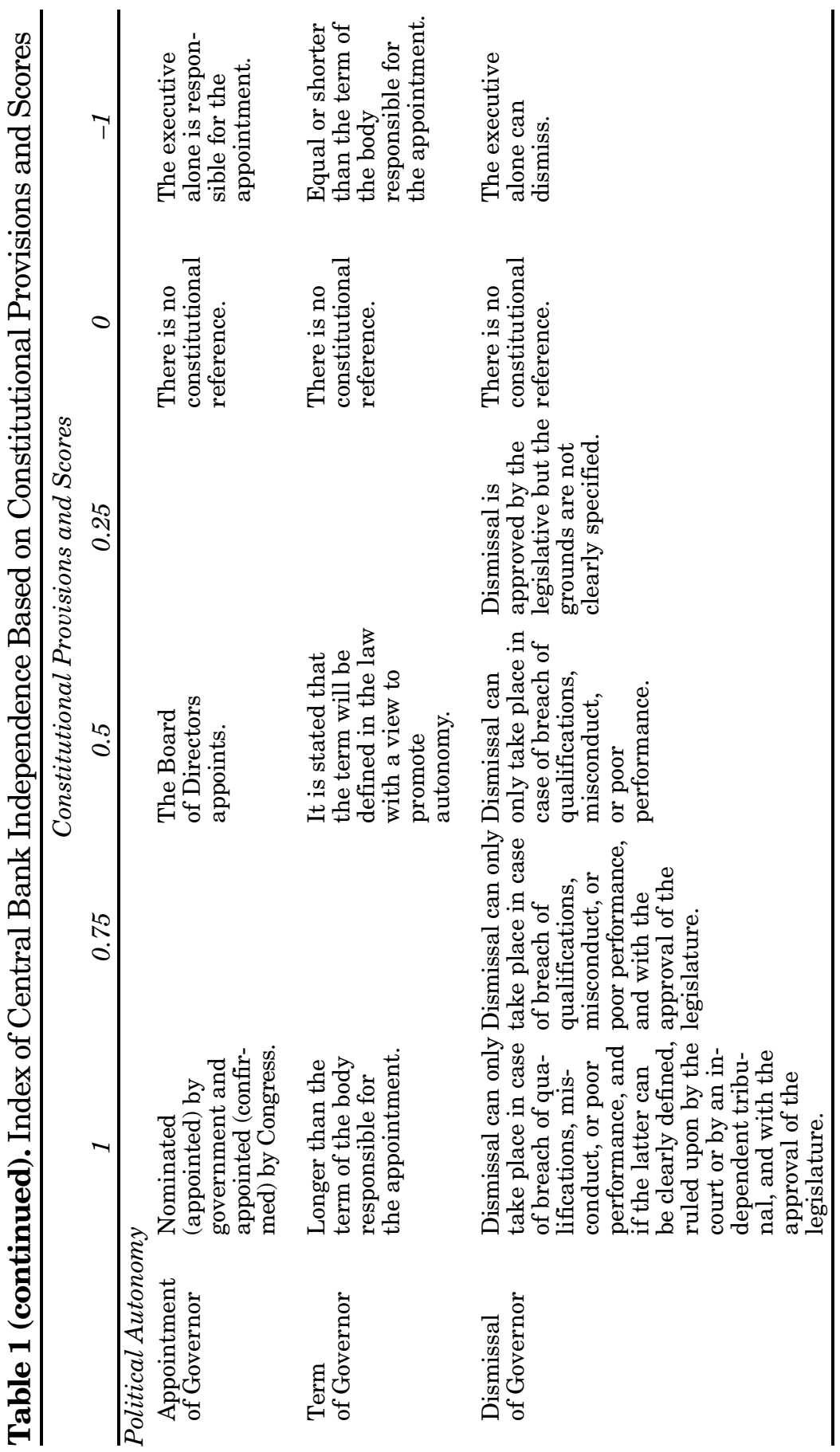




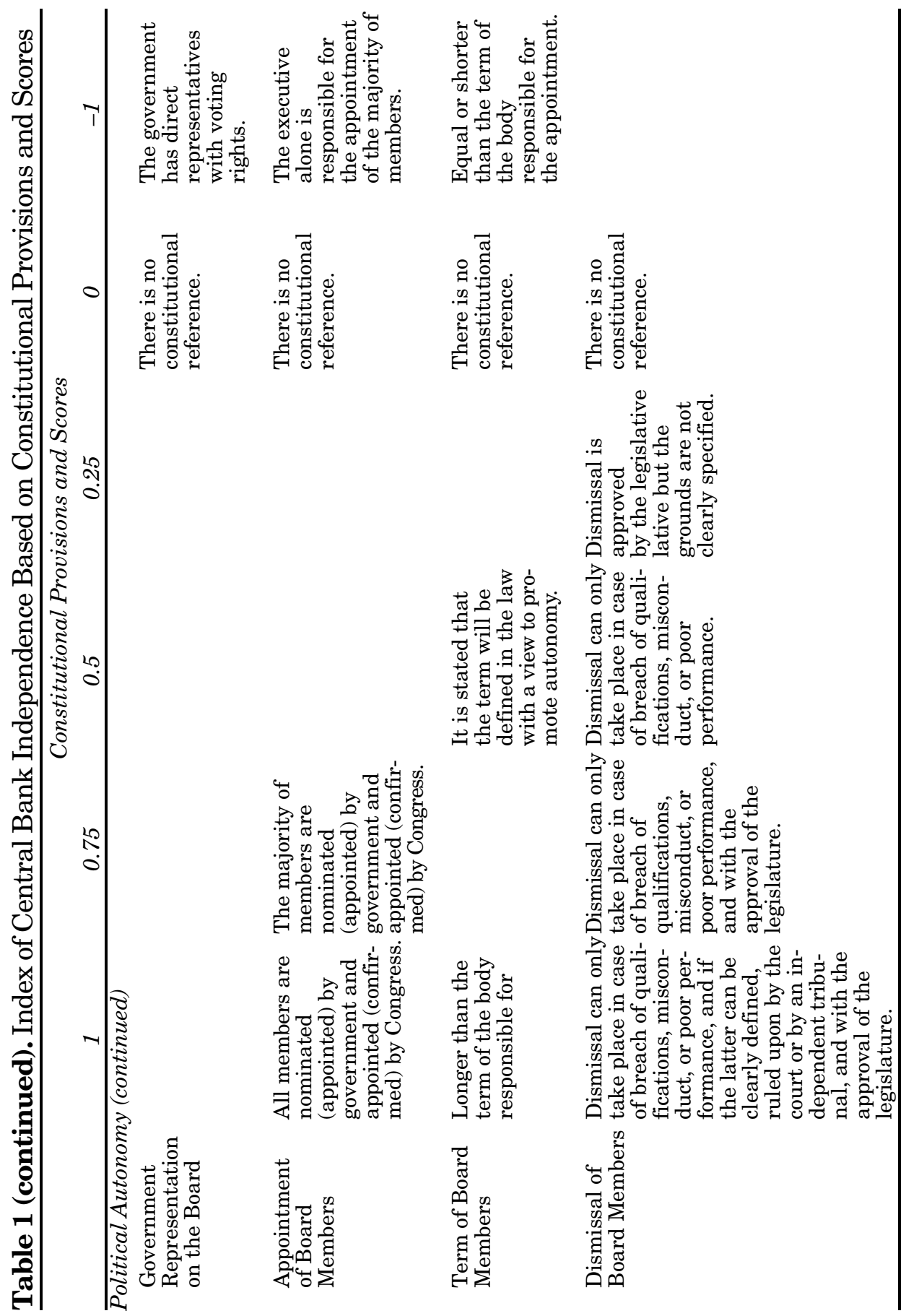




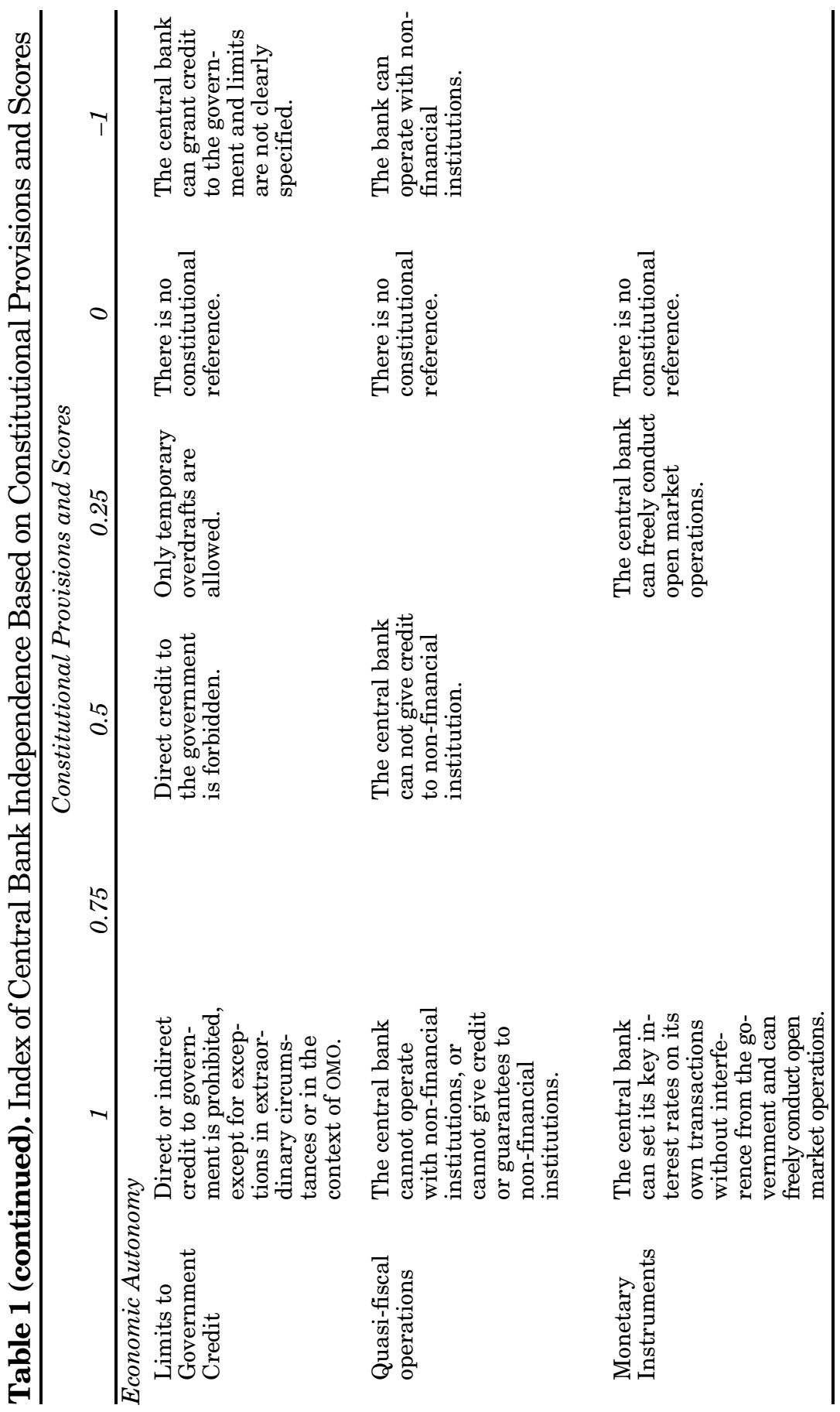




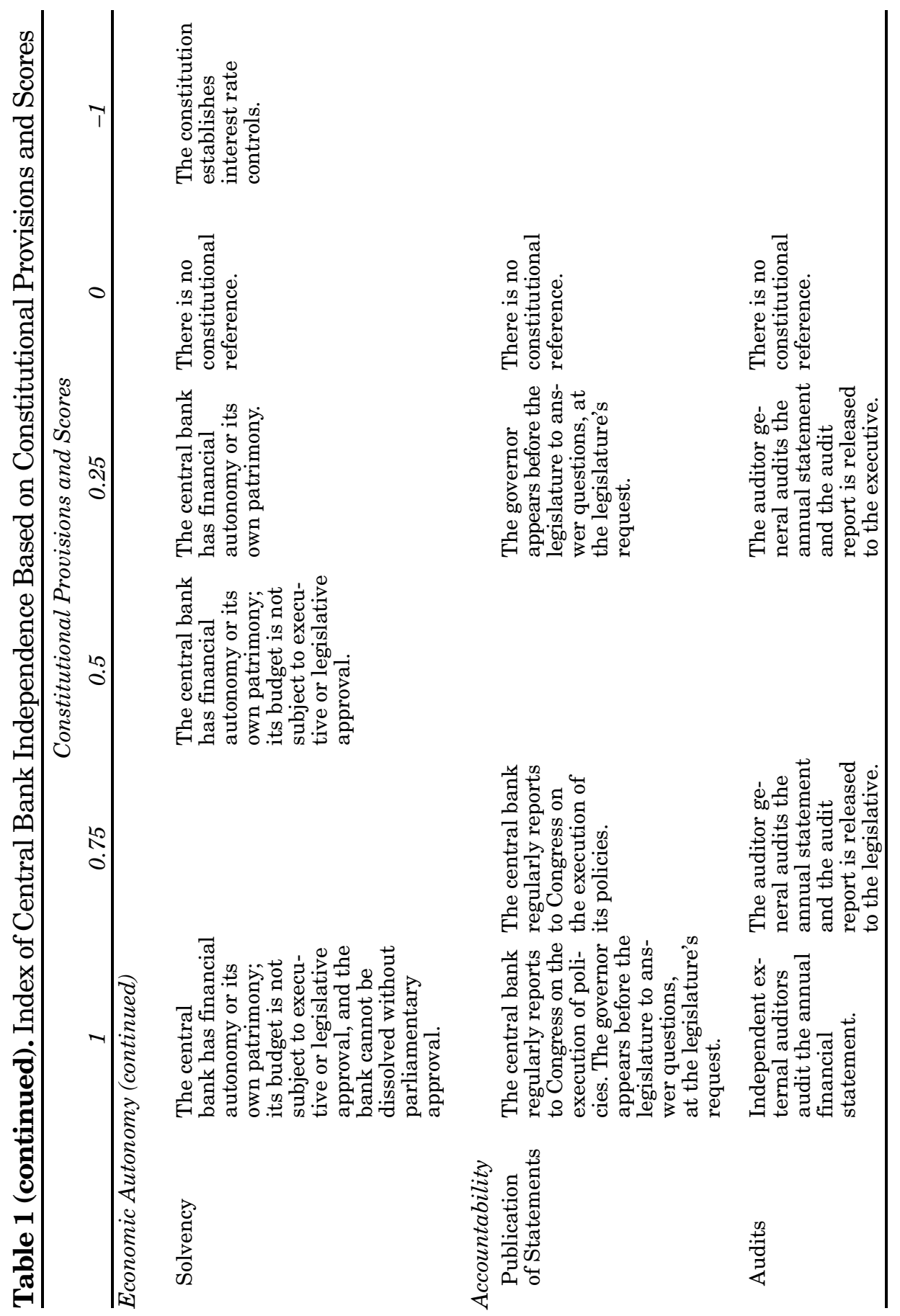


the preservation of price stability should be given to avoid policy conflicts. In this regard, delegation of banking supervision to an autonomous institution might prevent other objectives, related to the maintenance of the stability of the financial system, from interfering with the objective of price stability. ${ }^{9}$

\section{Central Bank Responsibilities in Monetary and Exchange Policy}

An independent central bank has autonomy to implement monetary and exchange rate policy in order to achieve its target. If the central bank has target autonomy, it can decide on the monetary target for achieving its primary objective. Under a regime of instrument autonomy, the central bank implements monetary and exchange rate policy according to a target determined by the cabinet or the legislative in agreement with the central bank. Decisions on policies to implement the target can be taken by the central bank without need to consult with the government. Both target and instrument autonomy confers great degree of independence to the central bank. Coordination with the government in the formulation of monetary and exchange rate policies help to avoid inconsistency in the targets and facilitates implementation by the central bank. Clear procedures to resolve conflicts between the government and the central bank thus enhance the independence of the bank. These procedures ensure that the government cannot overrule the central bank, or that the bank is not obliged to accept orders from the government, except during extraordinary circumstances, which should be promptly communicated to the general public. At the minimum, the procedures should allow the central bank to make public when it is forced to adopt decisions contrary to its opinion, so the public knows that the responsibility of the policies adopted at that point lies with the government.

\section{Political Autonomy of the Central Bank}

Political autonomy of the members of the governing bodies of the central bank is important to prevent undue short-term influence on mon-

${ }^{9}$ However, an autonomous central bank may be in some countries better suited to conduct banking supervision than a newer government agency. 
etary policy by the government or other constituencies. The composition of the central bank governing bodies and the procedures for appointment and dismissal of its members -as well as their term in office- determine the degree of political independence of the central bank. For example, the presence of government representatives with voting rights on the central bank board diminishes the political independence of the bank. Participation of both the executive and the legislative branches in the nomination and appointment of the governor and directors of the central bank reduces the scope for unduly politically nominated appointments. Dismissal of the governor and the board members should occur only for incapacity to perform their duties, which should be specified, and gross misconduct. The latter could be ruled upon by an independent tribunal and/or require approval by the legislature with a qualified majority. The term of office of the governor and directors should preferably be longer than the executive and legislative terms, in order to separate their term of service from that of the nominating or appointing authorities. However, for accountability purposes, it may prove useful to have external members represented on the board overseeing the bank.

\section{Economic Autonomy of the Central Bank}

The economic autonomy of the central bank refers to the capacity of the central bank to: $i$ ) control its own balance sheet; and ii) to affect liquidity levels and interest rates in order to implement its targets. Compulsory monetization of the deficit or injection of liquidity via operations with the private sector could compromise the achievement of the monetary policy targets. Prohibiting, or at least limiting, credit to government and non-financial institutions helps to ensure the economic autonomy of the central bank. Also, low profitability might induce the central bank to avoid tight monetary policy or to use direct instruments of monetary policy that may function as implicit taxes. Requiring executive or legislative approval of the central bank budget might subject the central bank to indirect political influence. Finally, the solvency of the central bank should be ensured to make the central bank economically independent of the government. 


\section{Accountability Procedures for the Central Bank}

Accountability procedures facilitate the control of central bank activities, policies and operations. Such control provides adequate incentives for the central bank to implement the policies to achieve the monetary policy targets. Transparency and accountability also protect the central bank from government intervention in the implementation of policies. To this end, it is important that the central bank regularly reports to the legislative branch or to the public on the execution of its policies, and that the central bank regularly publishes its audited financial statements.

The assigned value in the index used in this survey for the five broad categories described above is presented in Table 1 . All the former British and Dutch colonies do not include provisions dealing with the autonomy of the central bank in the Constitution; hence, those countries have a value of zero in the index. In some cases, the constitutional provisions explicitly undermine the autonomy of the central bank. In these cases, the value of the index for the different criteria is negative. For example, in the case of Bolivia and El Salvador, the Constitution establishes objectives other than price stability as the primary objectives of the central bank. In the case of Guatemala, the Constitution establishes that three members of the cabinet will also be members of the central bank board. ${ }^{10}$

Based on the index described below, we measured the de jure independence of central banks as established in the constitutions, in all Central and Latin American countries, as well as in most of the Caribbean countries. Table 2 summarizes the score in each of the five categories for all the countries in the sample. Details on how the countries rank in the different subcategories can be found in the appendix table.

The Constitution does not contain references to the central bank in $40 \%$ of the countries in the sample. Paraguay and Mexico are the countries with strongest independence as measured by the index. In the case of Paraguay, the high value is due to high scores in all categories compared to the average values, while in the case of Mexico is mostly due to the high score in the political autonomy category. On the other hand, the total value of the index for Colombia is negative, due to the scores in the political and economic autonomy categories.

10 The details on the components of the index are presented in the Appendix. 
Table 2. Country Classification According to Index

\begin{tabular}{lccccc}
\hline & Objectives & $\begin{array}{c}\text { Policy For } \\
\text { mulation }\end{array}$ & $\begin{array}{c}\text { Political } \\
\text { Autonomy }\end{array}$ & $\begin{array}{c}\text { Economic } \\
\text { Autonomy }\end{array}$ & $\begin{array}{c}\text { Accounta- } \\
\text { bility }\end{array}$ \\
\hline Argentina & 0.00 & 0.00 & 0.00 & 0.00 & 0.00 \\
Bahamas & 0.00 & 0.00 & 0.00 & 0.00 & 0.00 \\
Barbados & 0.00 & 0.00 & 0.00 & 0.00 & 0.00 \\
Belize & 0.00 & 0.00 & 0.00 & 0.00 & 0.00 \\
Bolivia & -0.25 & 0.00 & 1.00 & 0.00 & 0.00 \\
Brazil & 0.00 & 0.00 & 3.00 & 1.00 & 0.00 \\
Chile & 0.00 & 0.25 & 0.00 & 2.25 & 0.00 \\
Colombia & 1.00 & 1.50 & -2.50 & -1.50 & 1.00 \\
Costa Rica & 0.00 & 0.00 & 0.00 & 0.00 & 0.75 \\
Dominican & & & & & \\
$\quad$ Republic & 0.00 & 0.50 & 0.00 & 0.00 & 0.00 \\
Ecuador & 1.25 & 1.25 & 0.00 & 0.00 & 0.00 \\
El Salvador & -1.00 & 0.00 & 0.00 & 0.00 & 1.00 \\
Guatemala & 0.50 & 2.50 & -4.00 & 2.25 & 0.00 \\
Guyana & 0.00 & 0.00 & 0.00 & 0.00 & 0.00 \\
Haiti & 0.00 & 1.00 & 0.00 & 0.25 & 0.75 \\
Honduras & 0.25 & 2.75 & 0.00 & 0.00 & 0.75 \\
Jamaica & 0.00 & 0.00 & 0.00 & 0.00 & 0.00 \\
Mexico & 1.00 & 0.75 & 5.00 & 0.00 & 0.00 \\
Nicaragua & 0.75 & 0.25 & 0.00 & 0.00 & 0.75 \\
Panama & 0.00 & 0.00 & 0.00 & 0.00 & 0.00 \\
Paraguay & 0.75 & 1.25 & 3.00 & 1.25 & 1.00 \\
Peru & 1.75 & 0.25 & 0.50 & 0.75 & 1.00 \\
Suriname & 0.00 & 0.00 & 0.00 & 0.00 & 0.00 \\
Uruguay & 0.00 & 1.00 & 1.00 & 1.00 & 1.00 \\
Venezuela & 0.00 & 0.00 & 0.00 & 0.00 & 0.00 \\
Average & 0.24 & 0.53 & 0.28 & 0.29 & 0.32 \\
\hline
\end{tabular}

Average scores are similar in all categories with the exception of policy formulation, for which is higher. The sample dispersion is particularly important in the political autonomy category. While in some countries the Constitution specifies the governor and board members have to be nominated or appointed by Congress, can not be dismissed except for clear reasons, and can not be members of the government, in other cases, the Constitution indicates which government members have a seat at the central bank board. 


\section{Constitutional Central Bank Independence and Inflation Performance in Latin America}

During the 1980's, particularly the second half of the decade and the early 1990's, many Latin American countries experienced high inflation. Large fiscal deficits financed through monetization were in most cases at the root of the problem. With the goal of eliminating inflationary pressures, several countries reformed their constitutions to include provisions explicitly forbidding central bank credit to government (for example, in the case of Brazil, Chile and Guatemala). Some countries also entrenched the political independence of the central bank in the Constitution. Most of the countries did so by amending their Constitution in the late 1980's and early 1990's, coinciding with the inflationary periods. The exception was Chile, which introduced such constitutional provisions in $1980 .{ }^{11}$ Constitutional provisions were introduced in many cases ahead of changes in the central bank law (e.g., Brazil, Chile and Paraguay), or simultaneously (Mexico and Peru). Other countries, like Argentina and El Salvador, opted for a fixed exchange rate regime as part of a disinflationary program. Subsequently, average inflation decreased considerably in the continent during the second half of the 1990's (see Table 3).

To test whether the entrenchment of central bank independence in the Constitution results in lower inflation, we estimated the correlation (controlling for other factors) between the index discussed in the previous section and a measure of inflation during the period 1995-99. Following Cukierman (1992), we transformed the inflation variable to reduce heteroskedasticity of the error and thus improve the efficiency of the estimation. Using the conventional notation of $\pi$ for the inflation rate, our measure $\pi /(1+\pi)$ indicates the annual real depreciation of a given amount of money.

A first task is to assign weights to the different components of the index. Instead of assigning arbitrary weights, as typically done in the literature, we took the approach of letting the data reveal what are the components driving the correlation between inflation and our index of constitutional central bank independence. To do so, we estimated the following non-linear equation:

11 A new Constitution was promulgated in Venezuela in 1999, including a section on provisions dealing with the independence and accountability of the central bank. 
Table 3. Dates of Latin American and Caribbean Constitutions and Inflation Performance

\begin{tabular}{lcrrrr}
\hline & Amendments & \multicolumn{4}{c}{ Average Inflation } \\
& to Constitution & $1980-84$ & $1985-89$ & $1990-94$ & $1995-99$ \\
\hline Argentina & 1994 & 268.11 & 863.27 & 505.07 & 0.76 \\
Bahamas & 1973 & 7.44 & 5.12 & 4.33 & 1.32 \\
Barbados & 1966 & 9.85 & 3.92 & 3.32 & 2.45 \\
Belize & 1981 & 6.61 & 2.46 & 2.35 & 1.65 \\
Bolivia & 1994 & 351.97 & 2414.35 & 13.41 & 7.43 \\
Brazil & 1988 & 132.35 & 532.26 & 1667.21 & 19.35 \\
Chile & 1980 & 22.38 & 20.34 & 17.48 & 6.04 \\
Colombia & 1991 & 22.89 & 24.03 & 26.60 & 18.33 \\
Costa Rica & 1949 & 37.98 & 16.21 & 18.57 & 15.13 \\
Dominican & & & & & \\
$\quad$ Republic & 1994 & 11.54 & 30.21 & 23.06 & 7.44 \\
Ecuador & 1996 & 25.07 & 42.88 & 44.82 & 33.25 \\
El Salvador & 1982 & 13.74 & 23.30 & 15.74 & 5.47 \\
Guatemala & 1993 & 6.10 & 18.03 & 21.42 & 8.11 \\
Guyana & 1996 & $\mathrm{n} . \mathrm{a}$. & $\mathrm{n} . \mathrm{a}$ & $\mathrm{n} . \mathrm{a}$ & 7.00 \\
Haiti & 1987 & 10.53 & 2.70 & 25.02 & 17.61 \\
Honduras & 1982 & 9.89 & 4.91 & 19.71 & 19.77 \\
Jamaica & 1962 & 17.20 & 14.01 & 41.49 & 14.11 \\
Mexico & 1994 & 56.10 & 82.00 & 16.31 & 24.50 \\
Nicaragua & 1995 & 30.10 & 3357.61 & 2096.27 & 11.21 \\
Panama & 1983 & 5.81 & 0.49 & 1.11 & 1.08 \\
Paraguay & 1992 & 15.38 & 25.56 & 23.27 & 9.70 \\
Peru & 1993 & 84.08 & 878.57 & $1,607.41$ & 8.39 \\
Suriname & 1992 & 7.66 & 18.21 & 120.67 & 71.98 \\
Uruguay & 1997 & 44.20 & 70.96 & 76.36 & 21.38 \\
Venezuela & 1983 & 13.03 & 33.00 & 41.05 & 53.84 \\
\hline \multicolumn{1}{c}{ Soures } & & & &
\end{tabular}

Sources: IMF, International Financial Statistics; and Constitution Finder.

$$
y_{i}=x_{i}^{\prime} \beta+\alpha^{*} \Sigma_{j=1}^{5} \gamma_{j}^{*} z_{i j}+u_{i}
$$

where $y_{i}$ denotes our measure of inflation for country $i, x$ is a vector of control variables, $z_{i j}$ is the component $j$ of the index for country $i$, and $u_{i}$ is an error term.

As discussed in the previous section, we consider five components in the index - the objectives of the central bank, the authority over 
monetary and exchange rate policy, the political autonomy of the central bank, its economic autonomy and its accountability. We normalized the coefficient for the economic independence, $\gamma_{3}$, equal to one. In the vector of controls $x$, we include a constant term as well as variables that can potentially affect the inflation such as the public deficit as a percentage of GDP, the degree of openness of the economy, a dummy indicating whether the exchange rate is fixed, and a dummy indicating whether the country experienced a banking crisis during any of the years in the period. ${ }^{12}$ All variables - except for the dummiesare averages over the period 1995-99. Table 4 reports the results of the estimation.

The results of the estimation indicate that, controlling for other factors, countries that entrench the independence of the central bank in the Constitution tend to have lower inflation than countries that do not. The results indicate that the coefficient on the index, $\alpha$, is negative, and statistically significant. The components of the index that drive the result are the degree of economic independence of the central bank (whose coefficient was normalized to one) and the objectives of the central bank. That is, countries whose Constitution states that the primary objective of the central bank is price stability, and that forbid or limit central bank credit to the government and the private sector, tend to have lower inflation. The results also indicate that having a fixed exchange rate regime reduces inflation while the occurrence of banking crisis increases inflation, other things equal. The level of public deficit and the degree of openness of the economy turned out not to be significant. Regarding the public deficit, it might be due to the fact that we are controlling for the capacity of the central bank to resist public deficit monetization. If deficits are to be financed in an orthodox way, the impact on inflation is lower. Most surprising is the lack of significance of the openness variable, measured as non-oil imports and exports over GDP. Non-oil imports over GDP were also used as an alternative proxy for the competitiveness to correct for the fact that many countries are large commodity exporters. However, results did not change.

Using the weights for the statistically significant components of the index estimated in the non-linear regression above, we constructed

12 Following Leone, Jacome and Madrid (2001), the countries identified as suffering a banking crisis during any of the years of the period were Argentina, Ecuador, Mexico, Peru and Venezuela. 
Table 4. Estimation of Weights for Constitution-Based Index of Central Bank Independence

Dependent Variable

\begin{tabular}{lc}
$\pi /(1+\pi)$ & Equation 1 \\
\hline Public deficit & -0.003 \\
& {$[-0.850]$} \\
Openness & -0.000 \\
& {$[0.670]$}
\end{tabular}

Exchange rate dummy

$\left[-0.131^{*}\right.$

$-0.139 *$

$-0.144^{*}$

Banking crisis dummy

$0.112^{*}$

[-4.540]

$[-5.360]$

$\alpha$

[2.660]

$0.094^{*}$

$0.089 *$

[2.460]

$-0.027^{*}$
$[-2.870]$

[2.290]

-0.030 *

$-0.033^{*}$

[3.460]

$\gamma_{1:}$ Central bank objectives

$1.858^{*}$

[-3.660]

$1.275^{* *}$

[1.990]

$1.386^{*}$

[1.700]

$\gamma_{2:}$ Policy formulation

$-0.971$

[2.010]

$\gamma_{4:}$ Political autonomy

[-1.500]

$-0.585$

$-0.044$

[-1.460]

$\gamma_{4 .}$ Political autonomy

[-0.284]

$-0.007$

$\gamma_{5:}$ Accountability

0.069

[0.091]

[-.060]

Adjusted $R^{2}$

0.391

0.385

[0.660]

Note: $t$-statistics shown in brackets. Values with one and two asterisks at right are significant at, respectively, the $5 \%$ and $10 \%$ levels.

the index and run a linear regression of the measure of inflation on the index and the dummy variables. The results are reported in Table $5 .{ }^{13}$

Recent empirical work by Jacome (2001) finds no evidence that Latin American countries with independent and accountable central banks as reflected in the central bank legislation, have lower inflation. With a smaller sample of countries and a different period (19992001), he analyzes, using scatter plot graphs, the correlation between his index and the average rate of inflation. While he found a negative

13 Openness and public deficit variables, as well as cross terms between these variables and the index of independence, were included in the regression; however, they turned out not to be significant. We also ran the regression using inflation averages for 1996-99 and 1997-99 to test the robustness of the results. The results did not change. 
Table 5. Estimation of Correlation Between Inflation and Constitution-Based Index of Central Bank Independence

\begin{tabular}{lcc}
\hline $\begin{array}{l}\text { Dependent Variable } \\
\pi /(1+\pi)\end{array}$ & $\begin{array}{c}\text { Estimated } \\
\text { Coefficients }\end{array}$ & T-statistics* $^{*}$ \\
\hline Exchange rate dummy & -0.144 & -4.98 \\
Banking crisis dummy & 0.089 & 2.20 \\
Constitutional based & & \\
$\quad$ central bank independence index & -0.030 & -2.33 \\
Adjusted $R^{2}$ & 0.520 & \\
\hline
\end{tabular}

* $T$-statistics are robust to heteroskedasticity.

correlation between his index and inflation, the correlation was due to the presence of two outliers in the sample. ${ }^{14}$ The correlation disappeared when these two countries were removed. Using his same sample, we plotted our index of independence based on constitutional provisions against the average inflation for the period. We also found a negative correlation between our index and average inflation. Moreover, the correlation persisted after removing the two outliers (Argentina and Venezuela), that determined the correlation with the Legislation Based Index of Central Bank Independence (see Figure 1).

However, formal testing of whether entrenching the independence of the central bank in the Constitution results in lower inflation performance controlling for the fact that independence is entrenched on the central bank act remains to be done. To perform such a test, we followed the methodology of Jacome (2001) to construct his index of independence based on central bank legislation for the countries in our sample not included in his work, i.e., Bahamas, Barbados, El Salvador, Guyana, Haiti, Jamaica and Nicaragua. Unfortunately, legislation for Belize, Ecuador and Suriname was not available. The latest law to be enacted was the Nicaraguan Central Bank Act in 1999, also the year in which the new Constitution of Venezuela (not considered in the constitutional index) was approved. Since Venezuela as a high inflation country has proved heavily influencing the result of the regressions, we chose to include Nicaragua and drop Venezuela in our sample to analyze the period 1999-2001. The values for the two indexes are show in Table 6.

${ }^{14}$ Namely, Argentina and Venezuela. Argentina is the only country in the sample with a fixed exchange rate for the period. Venezuela is the only country in the sample that experienced a banking crisis during the period. In estimating the correlation plotting in the graphs, no additional variables are included to control for those factors. 
Figure 1. Comparison of Performance of Constitution-Based and Legislation-Based Indices of Central Bank Independence
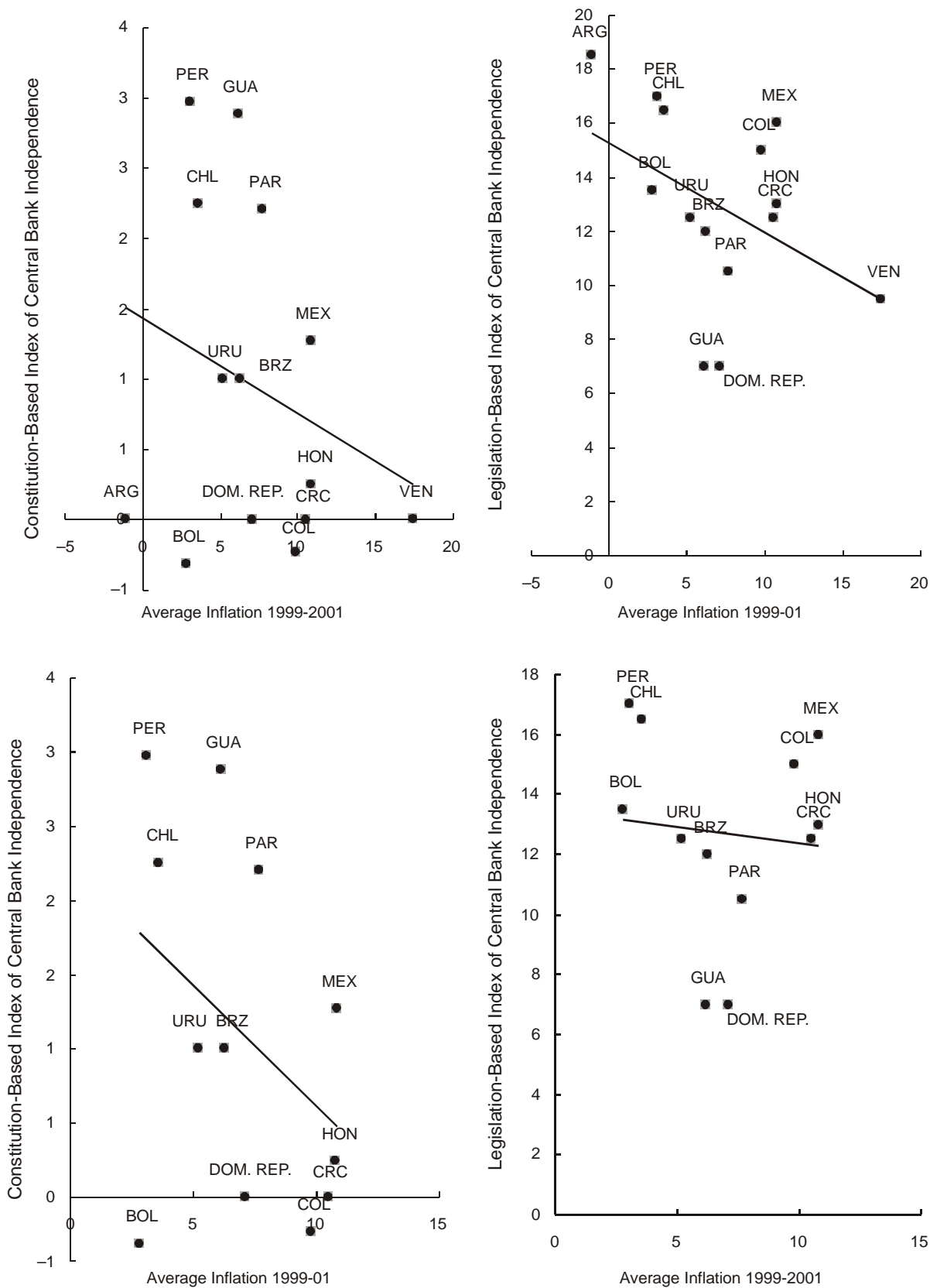
Table 6. Indices of Central Bank Independence for Latin American and Caribbean Countries

Legislation-Based Index of Constitution-Based Index of Central Bank Independence Central Bank Independence

\begin{tabular}{lrr}
\hline Argentina & 18.5 & 0.00 \\
Bahamas & 9.5 & 0.00 \\
Barbados & 9.0 & 0.00 \\
Bolivia & 13.5 & -0.32 \\
Brazil & 12.0 & 1.00 \\
Chile & 16.5 & 2.25 \\
Colombia & 15.0 & -0.23 \\
Costa Rica & 12.5 & 0.00 \\
Dominican Republic & 7.0 & 0.00 \\
El Salvador & 12.0 & -1.27 \\
Guatemala & 7.0 & 2.89 \\
Guyana & 13.5 & 0.00 \\
Haiti & 8.5 & 0.25 \\
Honduras & 13.0 & 0.32 \\
Jamaica & 5.5 & 0.00 \\
Mexico & 16.0 & 1.27 \\
Nicaragua & 14.5 & 0.95 \\
Panama & 9.0 & 0.00 \\
Paraguay & 10.5 & 2.20 \\
Peru & 17.0 & 2.97 \\
Uruguay & 12.5 & 1.00 \\
\hline
\end{tabular}

Although the correlation between the two indexes is positive as expected, it is rather low at 0.18 , reflecting the different ranking of countries depending on the indexes. For example, Guatemala has one of the lowest degrees of independence according to the law-based index, but ranks high on the constitution-based index. In this case, central bank law provisions regarding political autonomy of the central bank explain the low ranking in the central bank law based index. However, the constitution-based index only considers the objectives and economic independence of the central bank. The objective of preserving monetary stability and the prohibition to finance government deficits entrenched in the Guatemalan Constitution explain the high independence value on the constitution-based index. Table 7 presents the results of considering both indexes simultaneously. During the 
Table 7. Estimation of Correlation between Different Indices of Independence and Inflation Performance

\begin{tabular}{lccc}
\hline $\begin{array}{l}\text { Dependent Variable } \\
\pi /(1+\pi)\end{array}$ & Equation 1 & Equation 2 & Equation 3 \\
\hline Exchange rate dummy & $-0.115^{*}$ & $-0.068^{*}$ & $-0.068^{*}$ \\
& {$[-1.936]$} & {$[-5.010]$} & {$[-5.090]$} \\
Constitution-based index & & -0.008 & $-0.009^{* *}$ \\
& & {$[-1.530]$} & {$[-1.670]$} \\
Legislation-based index & 0.003 & -0.001 & \\
& {$[0.774]$} & {$[-0.678]$} & \\
Adjusted $R^{2}$ & 0.279 & 0.536 & 0.550 \\
\hline
\end{tabular}

Note: $T$-statistics shown in brackets. Values with one and two asterisks at right are significant at the $5 \%$ and $10 \%$ levels, respectively.

period 1999-2001, none of the countries in the sample experienced a banking crisis; therefore, that dummy variable is dropped from the regression.

The results indicate that, although the coefficient is lower than previously estimated, the Constitution-based index variable remains significant at the $10 \%$ level in a time period and country sample different from the previously considered. The legislation based index reduces the $t$-statistic slightly, enough to show that the index is no longer significant at the $10 \%$ level. However, the adjusted $R$-squared and the $t$-statistic for the legislation based index do not support the inclusion of the legislation based index in the specification. The legislation index alone does not result significant.

\section{Conclusions}

Economic theory suggests that the more independent the central bank is from political pressures, the lower the inflation in the economy, ceteris paribus. The proposition has been widely accepted by mainstream academics, policymakers and even markets. Empirical evidence from industrialized countries confirms that countries with a de jure independent central bank tend to have better inflation performance.

However, there is not much support for the theory when studying the relationship between de jure central bank independence and in- 
flation performance in developing countries. A possible explanation is that laws are less likely to be enforced or that political pressure may be exerted under the threat of modifying the legislation. ${ }^{15}$

\section{Appendix}

This paper explores the relationship between inflation performance and the level of independence of the central bank entrenched in the Constitution. Typically, constitutions are better enforced than ordinary laws given their superior legal rank. In addition, modifications typically required qualified majorities to make the Constitution much harder to amend than a law.

The results indicate that Latin American countries that entrench the independence of the central bank in the Constitution tend to have lower inflation, controlling for other factors. Particularly relevant is the inclusion of constitutional provisions forbidding or limiting central bank financing to the state and the private sector, and provisions establishing price stability as the primary objective of the central bank. The correlation, however, does not imply causality. Entrenching the independence of the central bank in the Constitution requires a higher degree of political consensus, and that consensus on fighting inflation, rather than the higher degree of enforcement of the Constitution, could explain the result. In any case, the degree of consensus can change over time. Entrenching the independence of the central bank in the Constitution has the effect of "tying the hands" of the legislature and the executive, who will require broader political support to modify the Constitution. The results have policy implications, particularly for countries with weak institutions and legal frameworks or with changing political objectives and a fragile political consensus. The results indicates that Argentinean legislators could consider enhancing the credibility of the central bank by entrenching its independence in the Constitution.

15 For example, the "superpowers" granted by the Argentinean Congress to the Minister of Economics in 2001 allowed him to modify the Central Bank Charter by decree. The result was a relaxation of the currency board agreement, by removing the limit on the flow of reserves that could be invested in domestic treasury bills. Currently, the Polish parliament is studying an amendment to the central bank law to include economic growth as one of the objectives of the Central Bank of Poland. 


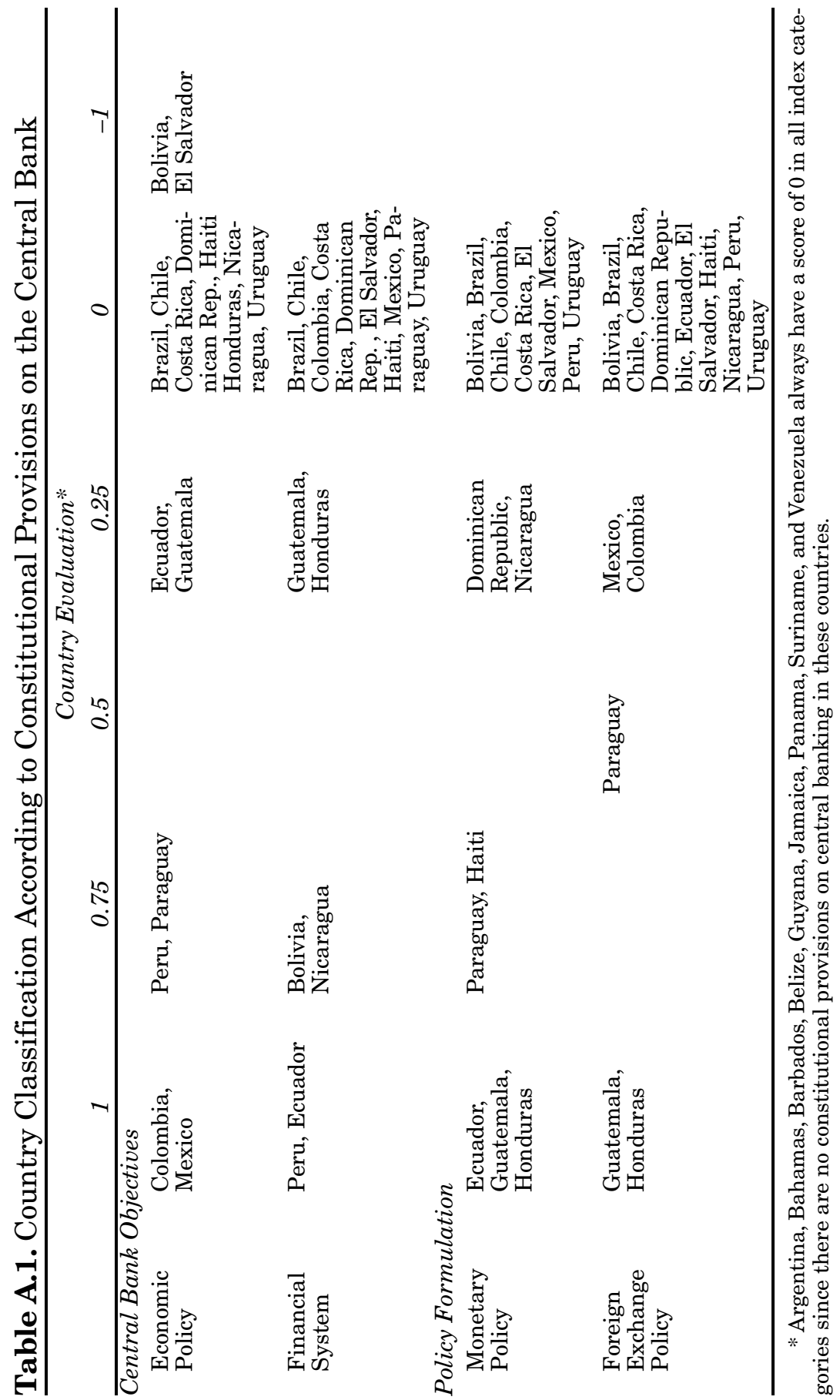




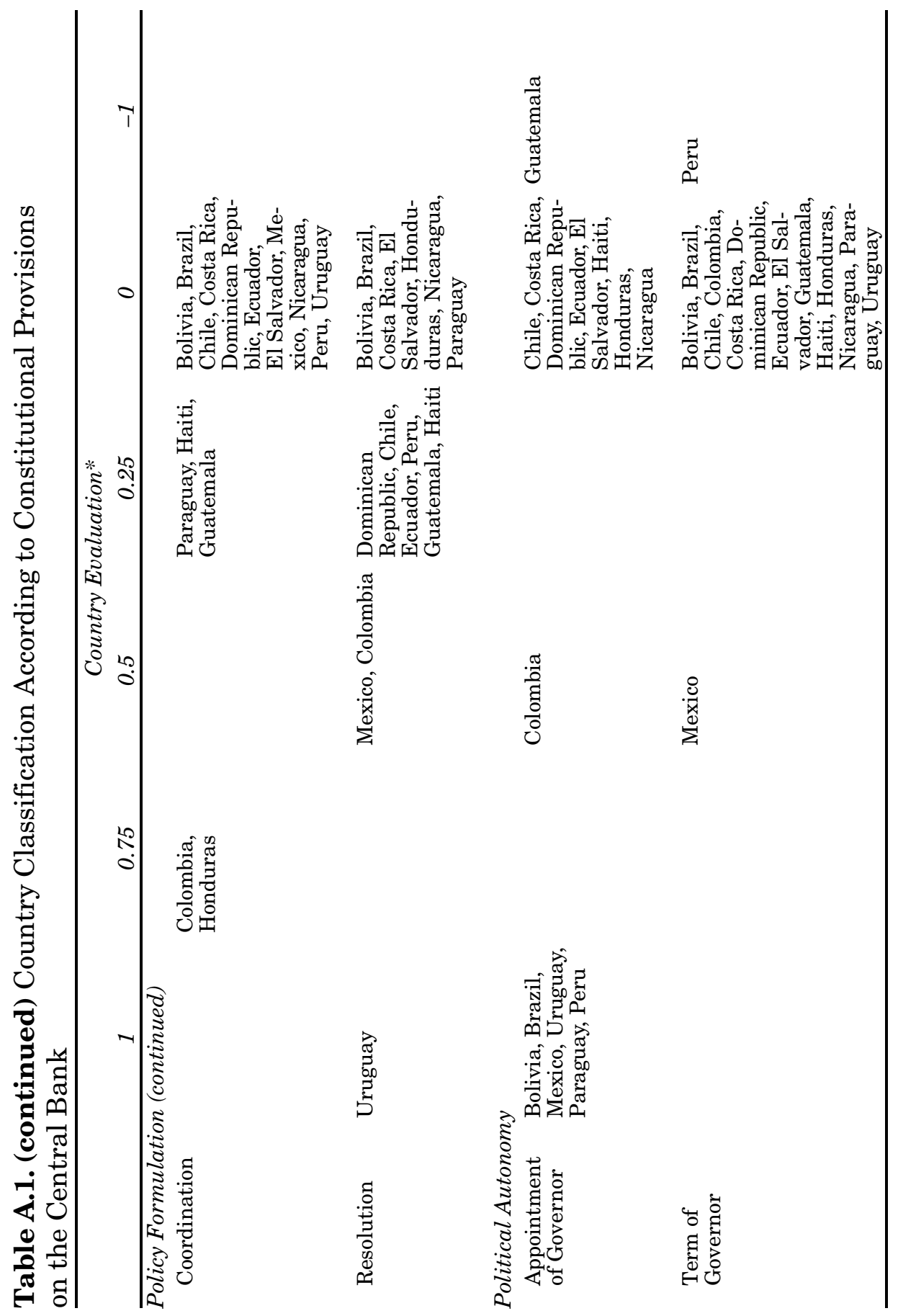




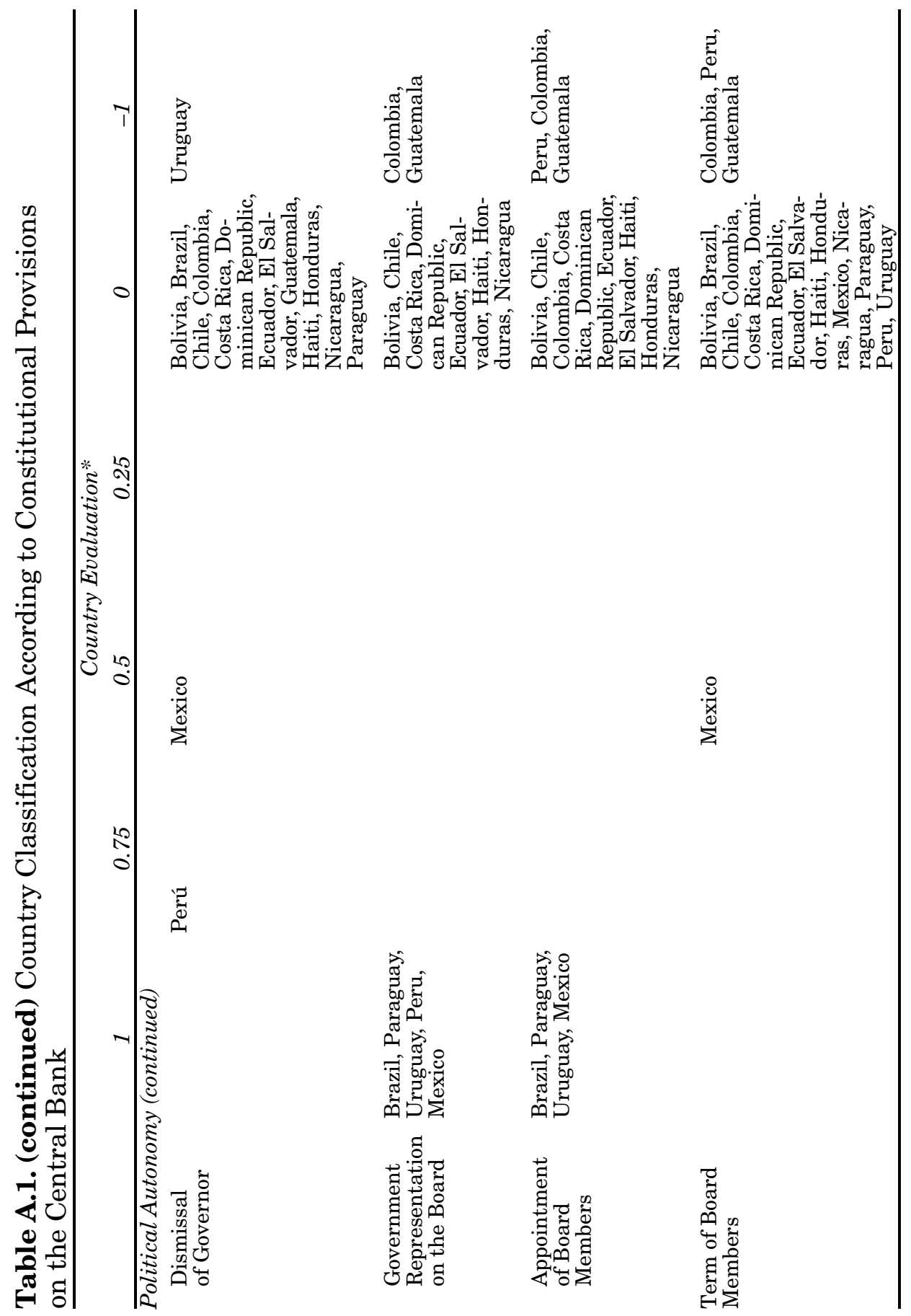




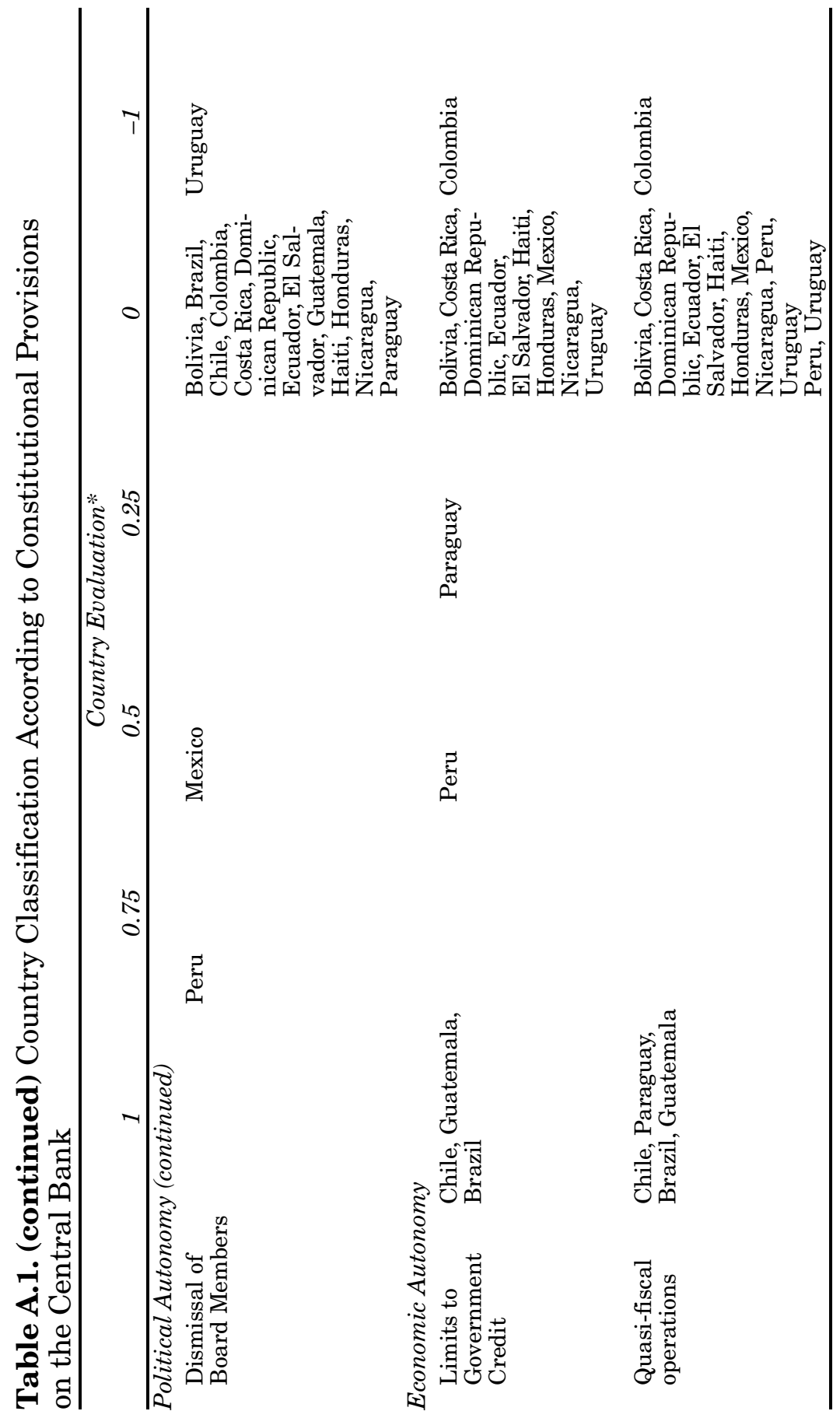




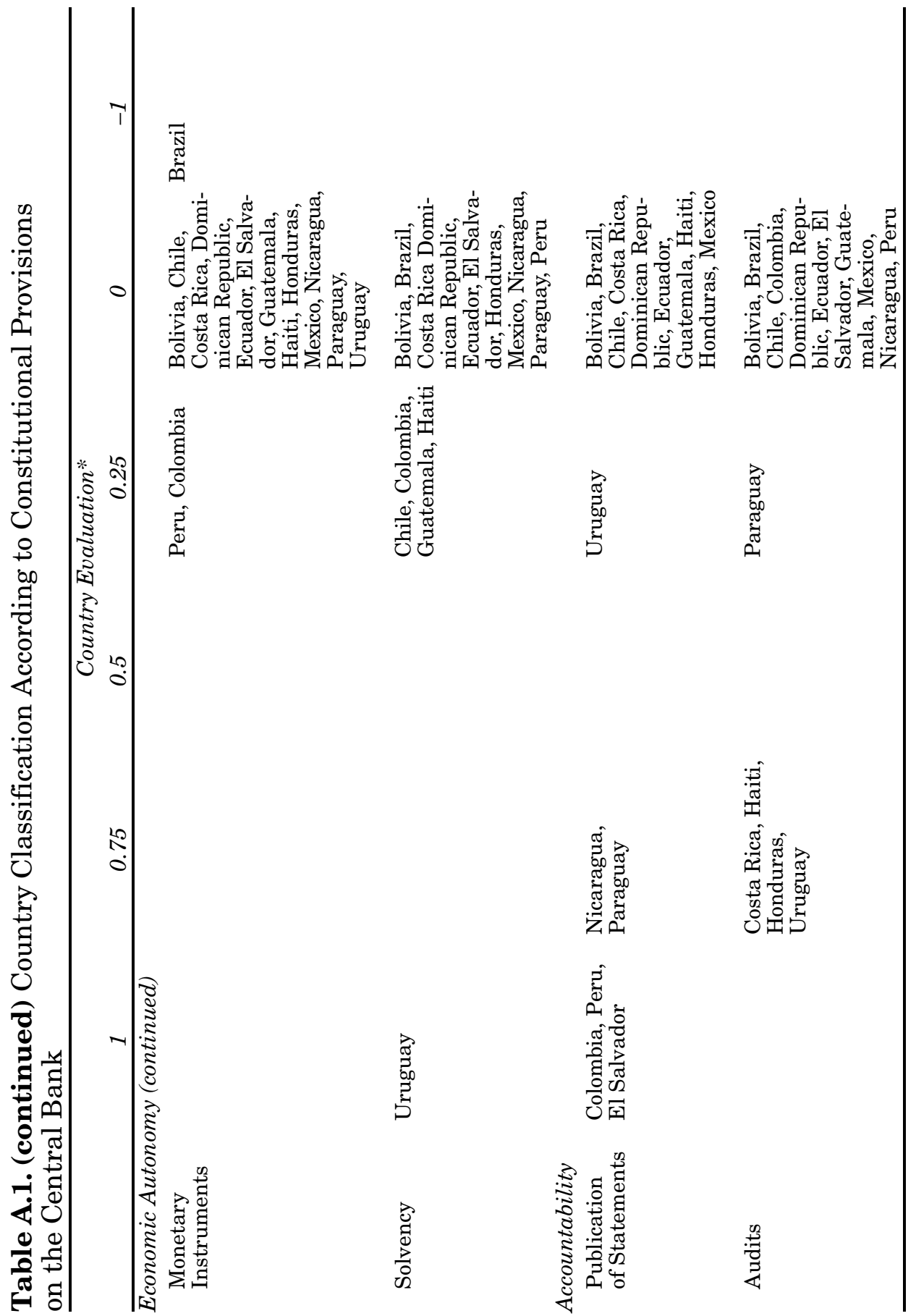




\section{References}

Alesina, A. (1988), "Macroeconomics and Politics", NBER Macroeconomics Annual, Cambridge Economic Press, Cambridge, Massachusetts. (1989), "Politics and Business Cycles in Industrial Democracies," Economic Policy, vol. 8 (April), pp. 55-98.

Al-Marhubi, F. and T. Willet (1995), “The Anti-Inflationary Influence of Corporatist Structures and Central Bank Independence: The Importance of the Hump-Shaped Hypothesis", Public Choice, vol. 84, pp. 158-62.

Andersen, T. and F. Schneider (1986), "Coordination of Fiscal and Monetary Policy under Different Institutional Arrangements", European Journal of Political Economy, vol. 2, pp. 169-91.

Berger, H., H. De Haan and S. Eijffinger (2000), Central Bank Independence: An Update of Theory and Evidence, CEPR Working Paper No. 2353, Center for Economic Policy Research, London.

Campillo, M. and J. Miron (1997), "Why Does Inflation Differ Across Countries?", in Christina D. Romer and David H. Romer (eds.), Reducing Inflation: Motivation and Strategy", University of Chicago Press, Chicago.

Cukierman, A. (1992), Central Bank Strategy, Credibility, and Independence: Theory and Evidence, MIT Press, Cambridge, Massachusetts. (1994), "Central Bank Independence and Monetary Control", Economic Journal, vol. 104, pp. 1437-48.

(1995), "Political Influence on the Central Bank: International Evidence", World Bank Economic Review, vol. 9, No. 3, pp. 397-423. Cukierman, A., G. Miller and B. Neyapti (2001), Central Bank Reform, Liberalization and Inflation in Transition Economies: An International Perspective, CEPR Working Paper No. 2808, Center for Economic Policy Research, London.

Cukierman, A., S. Webb and B. Neyapti (1992), "Measuring the Independence of Central Banks and its Effect on Policy Outcomes", The World Bank Economic Review, vol. 6 (September), pp. 352-98.

De Haan, J. and C. Siermann (1996), "Central Bank Independence, Inflation, and Political Instability", Journal of Policy Reform, vol. 1, No. 2, pp. 135-47.

De Haan, J. and W. Kooi (2000), "Does Central Bank Independence Really Matter? New Evidence for Developing Countries Using a New Indicator", Journal of Banking and Finance, vol. 24, No. 4, pp. 643-64. De Melo, M., C. Denizer, and A. Gelb (1996), From Plan to Market: 
Patterns of Transition, Policy Research Working Papers No. 1564, World Bank.

Eijffinger, S. (1995), "Central Bank Independence: Criteria and Indices", Kredit and Kapital, Especial Issue, No. 13, pp. 185-96.

Eijffinger, S. and J. De Hann (1996), “The Political Economy of Central Bank Independence", Special Papers in International Economics, No. 19 (May), pp. 1-70.

Eijffinger, S. and E. Schaling (1993), "Central Bank Independence in Twelve Industrial Countries", Banca Nazionale de Lavoro Quarterly Review, No. 184 (March), pp. 49-89.

Grilli, V., D. Masciandaro and G. Tabellini (1991), "Political and Monetary Institutions and Public Financial Policies in the Industrial Countries", Economic Policy: A European Forum, vol. 6 (October), pp. 342-91.

Jácome, L. (2001), Legal Central Bank Independence and Inflation in Latin America During the 1990s, IMF Working Paper 01/212, International Monetary Fund, Washington.

Leone, A., L. Jácome and P. Madrid (2001), Bank Restructuring and Central Banks in Latin America, IMF Working Paper, forthcoming, Washington, International Monetary Fund.

Loungani, P. and N. Sheets (1997), "Central Bank Independence, Inflation, and Growth in Transition Economies", Journal of Money, Credit, and Banking, vol. 29, No. 3, pp. 381-99.

Lybek, T. (1998), Elements of Central Bank: Autonomy and Accountability, Monetary and Exchange Affairs Department OP/98/1, International Monetary Fund, Washington.

(1999), Central Bank Autonomy, and Inflation and Output Performance in the Baltic States, Russia, and other Countries of the Former Soviet Union, 1995-97, IMF Working Paper 99/4, International Monetary Fund, Washington.

Malizszewski, S. (2000), "Central Bank Independence in Transition Economies", Economics of Transition, vol. 8, No. 3, pp. 749-89.

Managano, G. (1998), "Measuring Central Bank Independence: A Tale of Subjectivity and of its Consequences", Oxford Economic, No. 50, pp. 468-92. 